\title{
The Influence of Learning Activeness and Adaptive Reasoning on Students' Strategic Competence with Metaphorical Thinking Learning Approach
}

\author{
Haryanto \\ Universitas Negeri Yogyakarta \\ Yogyakarta, Indonesia \\ haryanto.ftuny@gmail.com
}

\begin{abstract}
This research aims to describe and examine the influence of learning activeness and adaptive reasoning on strategic competence of learning Intelligent Control System (ICS) course with metaphorical thinking learning approach. The type of research was a survey study. The population of this research included all students of the semester VI of Mechatronics Engineering Education. The sample in the study were the class $F$ students in the academic year of 2013 who were taking course of Intelligent Control System. Data collection techniques used observation, test, and question. Research instruments included a sheet of observation, Likert-scale questions form, and strategic competence tests of ICS. Data analysis techniques to answer the problem formulation used correlation and regression analysis. The results of the result are (1) there is a positive influence of adaptive reasoning on strategic competence of learning ICS for $R$ $=0.5806$ or $58.1 \%,(2)$ there is a significant and positive influence of metaphorical thinking learning on strategic competence of learning ICS for $R=0.3769$ or $37.7 \%$, (3) there is a positive and significant influence of adaptive reasoning and learning of metaphorical thinking together on strategic competence of learning ICS with $\mathrm{F} 45.202$ significant with the model of equation $y=-45.18+1.070 .87 \times 1+X 2$.
\end{abstract}

Keywords-adaptive reasoning; Intelligent Control System; metaphorical thinking; strategic competence;

\section{INTRODUCTION}

Intelligent Control System (ICS) is one of subjects under the curriculum of Mechatronic Engineering. This subject holds a strategic role in the development of Mechatronic Engineering. ICS also avails in developing other scientific fields. Learning ICS students can train to manage their active, logic, analitic, systematic, ctirical, and creative thinking, acquire cooperative ability to face problems, and make benefits of the gaining informations. To develop such competencies, according to Curriculum TIM (2014), the competencies are proposed as the basis of ICS learning in the current curriculum.

Learning process is a kind of educative learning, that is educational interaction which consciously have the golas to change people behaviors. Educational interaction conveys the two-direction active relation between teacher and students within knowledge as its medium. In the interaction, both elements of teacher and students must be active. It is impossible to have an educational interaction process if only one element is active, active in terms of attitude, mental, and behavior (Djamarah, 2000).

From teaching experiences done by the researcher, in general there is an indication that students' learning activities in ICS learning are insufficient, contributing to unoptimal learning outcomes. This is marked by the dominations of $\mathrm{B}$ score and under. It is also in line with a research study by Sumarmo (1993:55) on Senior and Junor High Schools and teachers of Kodya Bandung, of which the result reveals that Mathematics learning was generally less optimal since the students were less active during learning process. Indeed, Wahyudin (1999:6) asserts that in general Mathematics teachers employ lecturing and exposition methods.

Reasoning ability is a basis for learning ICS. To be based on teaching observations, students' difficulty in learning ICS is due to their lack of reasoning ability. Learning ICS demands the reasoning ability which is a necessary requirement for computer programming in ICS. It assumed that the students' low reasoning abilties are manifested by students' lacks of adaptive reasoning. Chairani (2010) and Rahmawati (2010) in their studies also inform the same matter, students' low adaptive reasoning ability. For that reason, it requires attempts to improve the adaptive ability in order that students can reach success in learning ICS, which still needs to be proven through this research.

Intelligent Control System highly bases on the mastery of Mathematics. Regarding to Mathematics, in the late recent years, conceptiual understanding and stategic competence gain much attention from experts in education. United States in a publication of book entitled Adding it Up: Helping Children Learn Mathematics in 2001 written by Kilpatrick, Swafford, $\&$ Findell, explains that conceptual understanding and stategic competence are two out of five mathematical skills to master in learning Mathematics.

According to Kilpatrick, Swafford, \& Findell (2001:116), conceptual understanding is an ability to comprehend mathematical concept, operation, realation. Regarding the importance of mathematical understanding component, ICS is oriented to fulfil the needs of the present time control system required for solving otomatization optimation, other scientific 
fileds, and everyday life problems. Next, strategic competence is an ability to formulate, present, and solve mathematical problems in ICS. Currently, mathematical conceptual understanding and strategic competence are considered not optimally acquired by students. In relation to those problems, it desires a right learning approach to escalate the students' ICS conceptual learning and strategic competence. One of the approaches which is quite relevant to be implemented is metaphorical thinking.

A conceptual thinking empasized on the ability to connect ideas and the existing phenomena is metaphorical thinking (Carreira, 2001:67). Metaphorical thinking is a process of thinking imposing on methapors to understand a single concept. Methapors departs from a concept already known to other concepts which are unknown and being learned by students (Hendriana, 2009:46). That is what underlies this research.

With regard to the whole explanation above, the conceptual understanding and strategic competence determine the students' success in learning ICS. The implementation of metaphorical thinking makes learning more meaningful because students can see the connection between concept which is learned and concept which is known. Students are expected to be able to realize that ICS is interesting and fun. Therefore, the researcher conduct study on the influence of learning activeness and adaptive ability to ICS learning strategic competence with applying the approach of metaphorical thinking. Also, this research study can be used by further researchers who are interested to conduct a deeper study on how to optimalise the students' conceptual understanding and strategic competence.

To be based on the background of the research above, the aim of this study is:

to examine, study, and to describe the influence of adaptive reasoning, metaphorical thinking learning, either individually or collectively, towards strategic competence of learning ICS course using the approach of metaphorical thinking.

\section{A. Learning Activeness}

Learning activitiy is students' involvement in the form of attitude, thought, attention, and skill in learning activities to support the teaching and learning process and to make benefits from such activities. Increasing in learning activity means increasing in the number of learners who engage in active learning, asking and answering, as well as interacting to discuss learning materials. Participatory teaching and learning method conducted by educators will be able to bring students to more take part and also be more opened and sensitive in the teaching and learning process.

Indicators of learning activeness can be viewed from: first, the majority of students in learning activities; second, the learning activity is dominated by students' activities; third, the majority of students are capable of competing tasks given by the teacher.

\section{B. Learning Activeness Adaptive Reasoning Ability}

1) Definition of Adaptive Reasoning Ability
According to Kilpatrick (2001:5) adaptive reasoning is capacity for logical thought, reflection, explanation, and justification. In other words, adaptive reasoning is the capacity for logical thinking about the connection between concept and situation, the ability for reflective thinking, explaining, and giving truths.

The definition is in line with NRC (2001) cited in Ostler (2011), adaption reasoning is loosely defined as the capacity for logical thinking and the ability to reason and justify why solutions are appropriate within the context of problems that are large in scope, while strategy competence refers to the ability to formulate suitable mathematical models and select efficient methods for solving problems.

Based on the description, adaptive reasoning is an important capability owned by students to support learning activities. A series of adaptive reasoning activities can train students to think logically and systematically to resolve problem properly. In this research, the adaptive reasoning ability mentioned is the ability of learners to solve adaptive reasoning matters. Students can show their capability as these three conditions are met, (1) possessing sufficient basic knowledge, meaning that students have good prerequisite abilities before assessing new knowledge to support the learning process, (2) the tasks are compehensible or understandable and motivting, (3) the given contexts has been acknowledged and is interesting for students (Kilpatrick, 2001: 130).

The conditions can be influenced by teaching, either learning model or learning media. Apperception, motivation encouragement, and challenging tasks are necessary to hold for demonstrating the students' adaptive reasoning ability. In case of this research, the three conditions are fulfilled with the applied learning model. The adaptive reasoning ability is implemented in each question items given to students.

Basically, adaptive reasoning ability is quite similar to mathematical reasoning. They are distinguished in some aspects: (1) mathematical reasoning has the indicators to manipulate, but adaptive reasoning does not; (2) adaptive reasoning covers deductive and inductive reasoning, generating conclusions are not only grounded on deductive formal justifying, but also on pattern, analogy, and methaphor; (3) learning with adaptive reasoning empasizes on either problem solving and students to use their thinking logically and systematically. In other words, students' logic and systematic thinking to solve problems should meet the situation and concept learned as well as the reason and evidence from a clear statement (Kilpatrick, 2001: 129-131).

\section{2) Aspects of Adaptive Reasoning}

Thompson et al. in Kaur (2012:92) develop a framework with six components for proof reasoning. The components are elaborated as follows.

\section{a) Discovering Through Counterexample}

Epp (1998) as cited in Kaur (2012:92) has proved that doing the discovery through counterexample is carried out easily by students than writing down formal proofs. In other words, students can use examples and not examples in the 
proofing process to improve their reasoning abilities in researching presumptions.

Question items can be modified for improving students' reasoning abilities. The modification is focused on aspect of making-mistakes estimation (Kaur, 2012:93). The modified points provide more benefits in discussions. Thus, students can perform reasoning to show the statements.

\section{b) Researching Conjectures}

As students finish answering the questions in the form of examples, they will know the final settlement in accordance with the given problems, whereas as the students are investigating presumptions, they will not know if their conjecture is true or false (Kaur, 2012:93). According to Kaur, when students postulate that statement is true, but at the moment of proofing, not in line with the conjectures, it means that they find other examples so that they get the correct statement but is not always true. Based on the modified questions they will explain their assumptions. Thus, their thinking will be exposed.

\section{c) Making Conjectures}

On the learning that employs student-centred approach, teachers use guided-discovery design, so that students can explore and discover patterns (Kaur, 2012; 95). According to Kaur, learners need courages to generalize patterns to make conjectures appropriately.

During the exploration and making conjectures about a concept, students will make a connection towards the concepts they have perceived (Kaur, 2012:96). Thus, the concept discovery ability can be reached well either throughout the activity of making or developing their conjectures.

\section{d) Developing Ideas}

Developing ideas, in this case, refers to writing general or formal opinions proofs (Kaur, 2012: 97). Kaur states that this is essential to confirm that students do not refer to many examples in making evidence. Generally, many students get confused as they start formal proving (Kaur, 2012: 98). Thompson also explains that there need specific argument or transparent pseudo-proofs, those are the firstly-established points before carrying out general proofs (Kaur, 2012:98). It is done in order that students write down the general proofs easily.

Therefore, the use of specific proofs can ease students to develop their thinking. It is due to the systematic points leading students to compose the general proofs.

\section{e) Evaluating Ideas}

In this component, students work for evaluating the given questions (Kaur, 2012: 101). In this case, students will have the advantages of mentioning various ways to solve problems. Therefore, educators emphasize problems on the aspects which should be evaluated by students.

Evaluating other opinions or ideas is a good task for students to explore themselves in small group, that is discussing about how to identify the weaknesses and to give clarifications (Kaur, 2012:100). Hence, students can reason through their strategy to evaluate others' opinions.

\section{f) Correcting Mistakes in Reasoning}

On the component of correcting errors in reasoning, that differs from evaluating ideas is that if students evaluate opinions, they will not know whether the opinions are true or not, whereas at the time correcting errors in reasoning students can acknowledge in advance that the presented statement was wrong, so that they should make correction (Kaur, 2012:102). Based on modified questions, learners are required to correct errors from the problems provided. Thus, learners will use the necessary capabilities, namely by linking the concept they already get to correct the wrong operation.

\section{Metaphorical Thinking Learning}

Metaphorical thinking is a thinking process using metaphors to comprehend a concept. According to Holyoak \& Thagard (Hendriana, 2009:46), metaphors move from a concept which is already known by students to other concepts which have not been acquired and have been learned. Furthermore, Hendriana (2009:46) explains that metaphorical thinking is operated to make one's mind clear related to their leaning activities. Forms of conceptual metaphors include: ideas which are liked to everyday experiences, building interconnection between two things such as: selecting, emphasizing, allowing, and organizing characteristics of the main topic with supports from additional topics in the forms of metaphorical statements, redefinition of the metaphors, and selection of the right one which is suitable for the topic to deliver.

Metaphorical thinking is a learning strategy which emphasizes on the students' metaphorical thinking ability. In this study the materials are not served as they are, but students are assisted to the self-discovery process of what to master through continuous dialogic process by leveraging the students' experiences.

From the definitions above, there are some points covered in the learning strategy of metaphorical thinking:

First, this learning strategy is grounded on thinking skill development, meaning that the expected goal is not solely to master a number of learning materials, but also to be able to develop ideas through verbal language skills.

Second, reviews of social facts or experiences become the basis for developing ideas based on students' daily social experiences and students' ability to describe their observation on various facts and data gained in everyday life.

Third, the final target of the learning strategy of thinking ability upgrading is students' ability to resolve social matters based on their levels of development.

\section{Strategic Competence}

According to the research result on mathematics learning, Kilpatrick, Swafford, \& Findell (2001:116) state that strategic competence is an ability to formulate, represent, and solve mathematical problems. The indicators of students' strategic competence are: understanding situation and condition of a problem; finding keywords and learning irrelevant matters; presenting a problem in various mathematical ways; selecting the right choice of problem-solving assistances; finding 
connections within a problem; selecting and developing effective methods to solve a problem; finding solutions from a given case (Kilpatrick, Swafford, \& Findell, 2001).

\section{RESEARCH METHOD}

This research studied the relation between variables as the research focus. Basis of survey research is to create a conclusion generalization from the research. The research is only conducted to the research sample but the research result is valid for all the population. This kind of research can be done for descriptive and explanatory purposes.

This is a survey research study, as it examines events that have already occurred at current time. This research examined the connection between the variables being the focus of the research. Basic use of survey research is to make a generalization of conclusions from the research. Research is only done to the samples but the results apply to the entire population. Survey research can be used for the purpose of descriptive, exploratory, and explanatory.

This research was carried out from April to October 2016. As for the research location, it selected Department of Electrical Engineering Education, Faculty of Engineering, Yogyakarta State University.

The research population included the students in Semester V. While the sample of the research was all students taking the course of Intelligent Control System.

Data collection technique used observation, test, and questionnaire. Observation was conducted to obtain data on activity processes done by lecturer and students in the teaching and learning process. Test was given to measure students' comprehensions on the Intelligent Control System materials. Questionnaire was distributed to obtain data on learnings conducted by teachers.

Check-list which was used to write and observe the process of teaching and learning during the research. The test was in the form of question items utilized to assess the students' comprehensions on the Intelligent Control System materials. The questionnaire consisted of questions with 4 alternative answers arranged based on Likert Scale. The instrument validity was done by applying content validity, while the reliability was analyzed with Cronbach's Alpha.

Analysis technique to evaluate the impacts of the implementation of learning method on the learning process on the course of Intelligent Control System was descriptive qualitative by examining students' questionnaires, learning involvement, reasoning, and strategic competence.

The questionnaire was the modified questionnaire used by Roger and Johnson (1994), Lancaster and Strand (2001) and Chong's (1999) instrument to figure out students' leaning activity and reasoning, as well as the feedback. Next, to test the influence of the method applied for students' strategic competence towards the materials. Furthermore, test to investigate the influence of the applied learning method towards the strategic competence of the students, multiple regression statistic is operated with an equation

$$
\mathrm{Y}=\mathrm{a}+\mathrm{b} 1 . \mathrm{LA}+\mathrm{b} 2 . \mathrm{ARA}+\mathrm{b} 3 \cdot \mathrm{MTL}+\mathrm{e}
$$

Here, "Y" is strategic competence of ICS, "LA": Learning Activeness, "ARA": Adaptive Reasoning Ability, "MTL": Metaphorical Thinking Learning. Hypothesis test is done in the significance level $\alpha=5 \%$.

\section{RESULTS}

Applying corelation and multiple regression, it is obtained the results of the research as presented in Table 1.

Based on data analysis using descriptive statistics it is obtained: (1) The mean of learning activeness is 35,06. It shows that there is a relatively high influence of learning activeness using metaphorical thinking learning strategy. The standard deviation is also low, indicated at 2,43.

TABLE 1. Result of Descriptive Analysis

\begin{tabular}{|l|l|l|l|l|}
\hline \multicolumn{1}{|c|}{ Statistics } & \multicolumn{1}{c|}{ LA } & \multicolumn{1}{c|}{ ARA } & \multicolumn{1}{c|}{ MTL } & \multicolumn{1}{c|}{ SC } \\
\hline Max & 40 & 74 & 58 & 85 \\
\hline Min & 30 & 66 & 48 & 30 \\
\hline Mean & 36.06 & 70.04 & 52.90 & 70.59 \\
\hline Ideal Mean & 25 & 50 & 37.5 & 50 \\
\hline SDi & 5 & 10 & 7.5 & 16.67 \\
\hline SDe & 2.43 & 2.11 & 1.80 & 11.47 \\
\hline
\end{tabular}

(2) The mean of reasoning ability is 70,04 . It shows that there is a relatively high influence of adaptive reasoning ability using metaphorical thinking strategy. The standard deviation obtained is quite low, that is 2,11. (3) The mean of metaphorical thinking learning is 52,90. It shows that there is quite high influence of metaphorical thinking learning towards strategic competence. The standard deviation is low at 1,80 . (4) The mean of strategic competence is 35,06 . This shows a relatively high influence of strategic competence using metaphorical thinking learning strategy. The standard deviation is achieved relatively low at 11,47.

Based on the result of statistical analysis of frequency distribution it concludes that: all variables (learning activeness, adaptive reasoning ability, metaphorical thinking learning, and strategic competence) belong to very good category. The gaining scores for each variable are presented in Table 2.

Based on data analysis using correlation, it obtains: (1) the correlation between learning activeness and strategic competence is $r=0,82$ and $R=0,6647$. This shows that there lies a relatively high and positive relationship or influence of adaptive reasoning ability on students' strategic competence. While the contribution of adaptive learning ability to strategic competence is also relatively high at $66,47 \%$. 
TABLE 2. Result of Frequency Distribution

\begin{tabular}{|r|l|r|r|l|r|r|r|r|r|r|r|}
\hline \multicolumn{2}{|c|}{ Learning Activeness } & \multicolumn{3}{|c|}{ Reasoning Ability } & \multicolumn{3}{c|}{$\begin{array}{c}\text { Metaphorical Thinking } \\
\text { learning }\end{array}$} & \multicolumn{3}{c|}{ Strategic Competence } \\
\hline Range & Category & Freq. & Range & Category & Freq. & Range & Category & Freq. & Range & Category & Freq. \\
\hline 10 & P & 0 & 20 & P & 0 & 15 & P & 0 & 0 & P & 0 \\
\hline 17.5 & F & 0 & 35 & F & 2 & 26.25 & F & 1 & 25 & F & 4 \\
\hline 25 & G & 4 & 50 & G & 3 & 37.5 & G & 5 & 50 & G & 20 \\
\hline 32.5 & VG & 47 & 65 & VG & 46 & 48.75 & VG & 45 & 75 & VG & 27 \\
\hline
\end{tabular}

Note: P(Poor), F (Fair), G(Good), and VG(Very Good).

(2) The correlation between adaptive reasoning and strategic competence is $r=0,76$ and $R=0,5805$. This indicates that there is a relatively high and positive relationship or influence of adaptive reasoning ability on students' strategic competence. The contribution of adaptive learning ability on strategic competence is relatively high at $58,1 \%$. (3) The correlation between metaphorical thinking learning and strategic competence is $r=0,61$ and $R=0,3774$. This shows a relatively high and positive relationship or influence of metaphorical thinking learning on students' strategic competence. Here, metaphorical thinking learning gives relatively high contribution $37,74 \%$ on strategic competence.

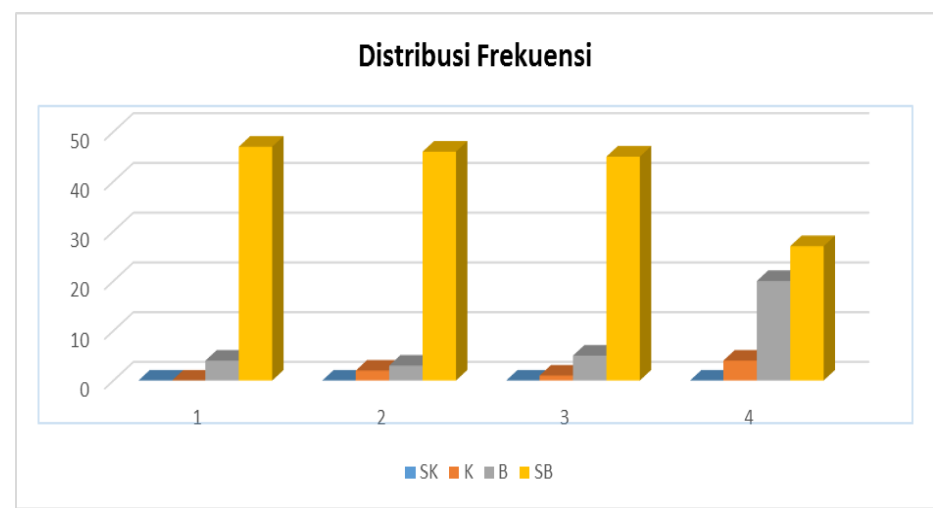

Fig. 1. Frequency Distribution

TABLE 3. Result of Correlation and Regression Analysis

\begin{tabular}{|l|r|r|r|r|}
\hline \multicolumn{1}{|c|}{ Statistics } & \multicolumn{1}{c|}{$\begin{array}{c}\text { Correlation } \\
\text { X1-Y }\end{array}$} & \multicolumn{1}{c|}{$\begin{array}{c}\text { Correlation } \\
\text { X2-Y }\end{array}$} & \multicolumn{1}{c|}{$\begin{array}{c}\text { Correlation } \\
\text { X3-Y }\end{array}$} & \multicolumn{1}{c|}{$\begin{array}{c}\text { Regression } \\
\text { X123-Y }\end{array}$} \\
\hline Correlation coefficient & 0.8153 & 0.7619 & 0.6144 & 0.8820 \\
\hline Coefficient of determination & 0.6647 & 0.5805 & 0.3774 & 0.7779 \\
\hline Contribution (\%) & 66.47 & 58.05 & 37.74 & 77.79 \\
\hline Regression Value & & & & 54.772 \\
\hline Constant & & & & -78.734 \\
\hline Regression coefficient X1 & & & & 2.332 \\
\hline Regression coefficient X2 & & & & 0.664 \\
\hline Regression coefficient X3 & & & & 0.409 \\
\hline
\end{tabular}

(4) The correlation between learning activeness, adaptive reasoning, metaphorical thinking learning together on student' strategic competence is $r=0,88$ and $R=0,7779$. This strongly indicates that there is a relatively high and positive relationship or influence of adaptive reasoning ability and metaphorical thinking learning on strategic competence. The contribution of adaptive reasoning ability and metaphorical thinking learning on strategic competence is relatively high at $77,79 \%$.

The results of regression analysis also show positive and significant impacts of adaptive reasoning and metaphorical thinking learning at the same time towards strategic competence in learning Intelligent Control System with $\mathrm{F}$ 54,77 and regression constant 78,73 ; regression coefficient for learning activeness variable at 2,33; adaptive reasoning ability at 0,66 ; regression coefficient for metaphorical thinking variable at 0,41 . Regarding these results the regression linear equation model within variables of adaptive reasoning ability and metaphorical thinking learning on strategic competence is

$$
y=-78.734+2.332 \mathrm{X} 1+0.664 \mathrm{X} 2+0.409 \mathrm{X} 3+\mathrm{e}
$$

the negative value of regression constant proves that to make strategic competence increase, it needs hard-working efforts to improve learning activeness at 2,33 , reasoning ability at 0,66 , and metaphorical thinking at 0,41 . 


\section{CONCLUSIONS AND SUGGESTIONS}

The research conclusions are listed as follows.

(1) there is a positive influence in learning activeness towards strategic competence of learning ICS at $\mathrm{R}=0,6647$ or $66,47 \%$.

(2) there is a positive influence in adaptive reasoning towards strategic competence of learning ICS at $\mathrm{R}=0,5806$ or $58,1 \%$.

(3) there is a positive and significant influence in the learning of metaphorical thinking towards strategic competence of learning SKC at $\mathrm{R}=0,3769$ or $37,7 \%$.

(4) there is a positive and significant influence of learning activeness, adaptive reasoning, and metaphorical thinking learning, at the same time towards strategic competence of leaning ICS with F 54,77 significant to equation model $\mathrm{y}=-78.734+2.332 \mathrm{X} 1+0.664 \mathrm{X} 2+0.409 \mathrm{X} 3+\mathrm{e}$.

\section{Suggestions:}

(1) Obtaining negative regression constant, it is necessary to work hard to improve the strategic competence, especially for efforts to improve the adaptive reasoning ability which does require high abstraction thinking.

(2) Obtaining relatively low regression coefficient for reasoning ability and metaphorical thinking learning variable, which is $<1$, it requires hard-working efforts to observation and guide students better in cultivating the adaptive reasoning ability.

(3) In addition, it is also necessary to carry out the more effective metaphorical thinking learning for the sake of the learning contribution to be meaningful and significant.

\section{REFERENCES}

[1] Arends, Richard I. 2008. Learning to Teach Belajar untuk Mengajar. Yogyakarta: Pustaka Pelajar.

[2] Hamalik, Oemar. 2011. Proses Belajar Mengajar. Jakarta: Bumi Aksara.
[3] Hanafiah, Nanang \& Cucu Suhada. Konsep Strategi Belajar. Bandung: Refika Aditama.

[4] Joyce, B., Marsha W., \& Emily Calhoun. 2011. Models of Teaching Eight Edition. Translated by Fawaid, Ahmad \& Ateilla Mirza. Yogyakarta: Pustaka Pelajar.

[5] Kilpatrick, Jeremy, \& Jane Swafford. 2001. Adding It Up Helping Children Learn Mathematics. Washington DC: National Academiy Press.

[6] Kaur, Berinderjeet \& Toh Tin Lam. 2012. Reasoning, Communication and connection in Mathematics. Singapore: World Scientific.

[7] Ostler, Elliott. 2011. Teaching Adaptive and Stategic Reasoning Through Formula Derivation: Beyond Formal Semiotic. International Journal of Science Education. 4(2): 16-26. Tersedia di www.tmrfindia.org/sutra/v4i22.pdf [diakses 29-12-2014].

[8] Sanjaya, W. 2007. Strategi Pembelajaran Berorientasi Standar Proses Pendidikan. Jakarta: Media Prenada.

[9] Shadiq, F. 2004. "Pemecahan Masalah, Penalaran, dan Komunikasi". Paper presented at Diklat Instruktur Pengembangan Matematika SMA Jenjang Dasar, 16 - 19 August 2004. PPPG Matematika. Yogyakarta.

[10] Silberman, Mel. 2009. Active Learning: 101 Strategi Pembelajaran Aktif. Translated by Sarjuli, Adzfar Ammar, Sutrisno, Zainal Arifin Ahmad, \& Muqowim. Yogyakarta: Pustaka Insan Madani.

[11] Sudjana. 2005. Metoda Statistika. Bandung: Tarsito.

[12] Sugandi, A. 2008. Teori Pembelajaran. Semarang: Unnes Press.

[13] Suryobroto, B. 2009. Proses Belajar Mengajar di Sekolah. Jakarta: Rineka Cipta.

[14] Syah, Muhibbin. 2008. Psikologi Pendidikan dengan Pendekatan Baru. Bandung: Remaja Rosadakarya.

[15] Tang, Guoqing \& Aaron Titus. 2003. "Promoting Active Learning in Calculus and General Physics trough Interactive and Media-Enhanced Lectures". Journal of Mathematics, Physics, and Chemistry Departments at North Carolina A\&T State University, 2 (1): 49-56. Available at www.iiisci.org/journal/CV\$/sci/pdfs/P977741.pdf [accessed at 14-1-2015].

[16] Trianto. 2010. Model Pembelajaran Terpadu Konsep, Strategi, dan Implementasinya dalam Kurikulum Tingkat Satuan Pendidikan (KTSP).Jakarta: Bumi Aksara.

[17] Usman, Moh. Uzer. 2009. Menjadi Guru Profesional. Bandung: PT RemajaRosdakarya. 